ALINA BUZATU

\title{
GENRE AS A CONCEPTUAL TOOL
}

Throughout its semantic route to what it is today, the concept of genre has been under the auspices of ambivalence, traversing epochs of prestige and privileges and epochs of theoretical impasse. Like any concept of such amplitude, genre has the quality of a superordinate entity: the complex diachronic and synchronic relations developed with other conceptual families are a dialogic game of mutual interrogations, transformations, appropriations, quarrels or divorces. The concept of genre is present in the group photo of each episteme.

Should we reduce the prodigious multiplicity of socio-cultural situations that genre systems have crossed, we would find two main theoretical scenarios; in the first scenario, genres are represented as biological species, organized on the basis of their common characteristics, entities that live, grow up, reach maturity and die. In the second scenario, genres are seen as institutions that promulgate laws that methodologically regulate discursive structures. Both perspectives are incorporated in various texts that form the theoretical canon; both have strengths that have been exploited and weaknesses that have been objected to.

As we well know, before the beginning of the 20th century the taxonomies of genre were captive in a rigid triad - the epic/ the lyrical/ the dramatic - a representation whose effectiveness is, and has always been, questionable when confronted with the immense richness of literary facts. At present, we are obviously witnessing a transformation of genre as a conceptual tool, so it is important to ask questions about its validity and meaning. In other words, the very general questions that concern us - together with the many literary theorists who have recently formulated observations on the condition of this concept - are the following: Is it a resilient, appropriate and effective tool in the current sociodiscursive circumstances, when confronted with the emerging forms of fiction/ literature/ literariness? What will its future uses be? Will it remain a specialized instrument or will it be a common convenience, shared by larger communities? Beyond the educated guesses, the affirmative answer - yes, genre is an instrument that will enter the conceptual kits of future generations - requires some nuanced arguments. It should be said that genre is an indispensable concept that deserves to be safeguarded if we respect its capital of theoretical and critical experience.

The antifragility ${ }^{1}$ of the genre as a conceptual tool, its capacity to withstand shocks and replicate must be emphasised: in its recent history - from the beginning

\footnotetext{
${ }^{1}$ The term is borrowed from Nicholas Nassim Taleb's book, Antifragile: Things That Gain from Disorder, New York, Random House, 2012.
}

DACOROMANIA LITTERARIA, VI, 2019, pp. 83-89 
of the 20th century to the present - the concept of genre has gone through two revolutions that are commonly known as the linguistic turn and the cognitive turn. What does genre as taxonomic tool look like at present? First of all, genre has acquired not only other functions and values but also other "tags". At this point, "tags" such as epic, lyrical, dramatic are terms used either in their categorial sense, without their historical, normative value, or with mechanistic meanings, as they are unfortunately perpetuated by school textbooks. These tags do not cover clearly defined territories - in each epoch they are subject to semantic reconfiguration and do not index stable identity features; that is why many theorists prefer to use quasi-synonyms for it, such as archigenre, mode, genre model, textual type, etc., each displaying other critical specifications.

The definitions of genre are intrinsically related to the logic of literariness. For centuries, from Aristotle to the beginning of the 20th century, the definitions of genre were related to an essentialist logic, according to which some texts have a kind of literary aura, obtained by means of fiction, freed from the criterion of truth; Frege and those who followed him taught us that fiction is neither true nor false, only possible, based on the famous contract of mutual irresponsibility (or "willing suspension of disbelief") between the addresser (author) and the addressee (communities of readers). For Aristotle and the whole tradition he opens, language is creative when it comes to fiction, and creativity is achieved not verbally, but at the level of invention, of the representation and combination of events (in two registers, narrative and dramatic and two levels of dignity of subjects, noble and vulgar). It is not by accident that Gérard Genette - who critically glosses upon these ideas in two essential metatheoretical textbooks, Introduction à l'architexte (Paris, Seuil, 1979) and Fiction et diction (Paris, Seuil, 1991) - translates (following Käte Hamburger) mimesis as fiction. On one hand, essentialism has incontestable merits - see Hamburger's Die Logik der Dichtung, in which only two fundamental genres are recognized: the fictional genre and the lyrical genre, both marked by different enunciative postures; on the other hand, essentialist logic is the source of deformed ideas, especially among less cultured communities which equate fiction, more precisely narrative fiction, with literature itself.

It is the merit of the 20th century to have changed the logic of the definition: essentialist approaches are replaced by conditionalism, which gives prevalence to formal (or rhematic) criteria. As the German Romantics, Mallarmé, or Valéry imagined and affirmed, literariness cannot be equated only with a set of privileged themes and images packed in a 'transparent' language. The 'package' (i.e. the signifier) becomes a layer that can no longer be separated from content; in other words, the discursive sublimations become intransitive, in the sense that they take a form that they become inseparable from, thus distancing themselves from the world and setting up a pseudo-referential level. Therefore, it is diction, not fiction that becomes prevalent and will command affiliation to one genre or another. The best known theoretical product of this conception is, of course, Roman Jakobson's poetic function. 
The reconstitution of the contemporary theoretical issues concerning genre exceeds the intentions and possibilities of any limited research. There are so many titles of secondary literature, so many doctrines and schools of thought that the choice of a point of view or another becomes, in the end, a matter of taste. Nevertheless, in this nostalgic cartography, some landmarks cannot be eluded. The first conditional codifications of genre are the intellectual property of Russian Formalism: generic taxinomies are problematised by Boris Tomashevski, Victor Petrovski, Vladimir Propp, Sklovski, etc. Focusing on the narrative, the Russian formalists do not operate with sophisticated theoretical presuppositions: for them, the literary genre is related to procedures, understood as a sort of constructive blocks, linguistic prefabrications that can build (or, more precisely, counterfeit) a literary object. Following their directives, the progressive conceptual formalizations of genre incorporate the exaltations of narratology, which also relies on procedures in the work of edifying a text, and then the lucidity of semiotics. Narratology has succeeded in producing models of interpretation of narrative text that are extremely useful form the didactic point of view, even if they may be sometimes blind to aesthetic value; the various narratological schools have taught us to deconstruct a narrative sequence, identify the voices and the focalisation, follow the scenarios or discriminate among the actantial structures.

Another fundamental genre adjustment as a conceptual tool comes after the structuralist age. After the $1960 \mathrm{~s}$, genre ceases to be the natural property of literature and becomes an asset of the entire human discourse. If, for example, narrative is present in many cultural products other than linguistic texts (film, comics, drawings, librettos, ballet, as Roland Barthes states in a founding text ${ }^{2}$ ), why should genre remain only a literary notion? In his later writings (Esthétique de la création verbale, for example), Mikhail Bakhtin raises the concept of genre to another level of theoretical power, explaining that literary genres are a secondary case of the discursive genres; the experience of genre is part of a cultural instinct that is constantly educated and found in the mental foreground of any act of enunciation. Genre is an efficient aid in the vast interdiscursive field that is the socio-cultural life, providing us with a number of labelled boxes to organize our utterances and the utterances of others; in other words, genre grants identity to speech acts, asserts their duration, negotiates the semiotic contract, programmes memorisation. Bakhtin's theoretical solution is still valid today, although at this point it has to be said that there cannot be a simple inclusion ratio between the literary genres and the discursive genres. The genres of literature are secondary to the genres of discourse, but this does not mean that all their properties are the result of a derivation that is always intelligible or quantifiable. If literature does not exist as essence, at least the existence of the literary field is indisputable, displaying specific agencies, institutions, goods, interests and values. The literary texts have a

${ }^{2}$ See Roland Barthes, Image-Music-Text. Translated by Stephen Heath, London, Fontana Press, 1977. 
different symbolic status and a specific semiotic manifestation mediated by genre, which 'works' in a more complicated way in the space of literature and therefore cannot be labelled as readily as other discursive practices. This is the most legitimate protest of those who defend the historical claim of literature on the concept of genre and see these other improper uses as sad consequences of theoretical commodification.

An important recalibration of genre as a conceptual tool is to be found in the 1970s. Reputed theorists such as Jean Michel Adam, Dominique Maingueneau, Francois Rastier, Jean-Paul Bronckart, and especially Teun van Dijk, all affiliated to the vast field of research called discourse analysis, have brought the most substantial transformations to the concept in its recent history, establishing fortunate interdisciplinary alliances between language sciences, on the one hand, and cognitive (neuro)sciences, on the other. Through their effort, the instauration of the cognitive paradigm was not fatal to the concept of genre, but it meant a verification of its epistemological efficiency. Modulated by discourse analysis, the concept of genre was able to 'learn' from the discoveries of cognitivism and recalibrate itself, or, in the terms of Nicholas Taleb, demonstrate its antifragility.

Although methodological differences are many, all practising theoreticians in the field of discourse analysis - be it Jean Michel Adam, Jean Marie Schaeffer, Dominique Maingueneau or Francois Rastier - agree on a new name/ tag for genre matrices: type. The types (5 for Jean Michel Adam: narrative, descriptive, dialogical, argumentative, explicative) represent global and abstract modes of textual organization, stable and invariable, grounded in the deep structure, on universal cognitive operations and actualised at the surface level according to historical and cultural circumstances. The fundamental role of genre/ type is that of mediation, as Rastier points out, along the lines of a hermeneutical approach: symbolic mediation by articulating the individual with the social and semiotic mediation between the actual world and the worlds of (discursive) representation. Rastier is also the one who renounces excessive formalizations, discussing genre signals (or genre markers) not only at the level of the signifier but also at the level of the signified, following the thematic, dialectical, dialogical and tactical game of contents and thus establishing the conceptual framework of a genre semantics.

The theorist who manages to reconcile the concept of genre (after decades of linguistic formalization) with the cognitivist paradigm is Teun van Dijk; his methodology, called socio-cognitivism, is broadly discussed in several books, of which the most important are Discourse and Context and Society and Discourse. First of all, Teun van Dijk recalls an intuitive idea exploited by linguistics, psychology, sociology and anthropology: the genres/ types carry mental schemata and scripts - or scenarios if you prefer - that is, matrices of thought and behaviour that organize categories of information and relationships between them. When we learn to deconstruct a literary text, discriminating, for instance, narrative from descriptive sequences, we operate with a kind of prior knowledge, with something that we already know. It is amazing how few people realize that similar processes 
are always active in our minds. At every moment of our discursive existence, we know - even if we do not know that we know - how to identify participants, assign roles, measure variations in style and register, because our private encyclopaedias discreet, indeed, but always in charge - contain genre rules and conventions. Van Dijk's theories are the sociolinguisitic extension of the formulations of Gilles Fauconnier and Mark Turner in their fundamental book The Way We Think. Conceptual Blending and the Mind's Hidden Complexities, according to which conceptual blending, the mental process with a decisive role in human existence, choreographs vast semantic construction networks such as categorizations, analogies, scientific constructions, and, in the most interesting case, the construction of the unreal. In all these cases, we operate with mental schemata. However, these mental schemata are never "empty" of meaning, nor are they indifferent to the context in which they are represented, because they are not just a set of steps in an algorithm written only at the level of the signifier. Their meaning, inherently plural, as we know, comes - as Teun van Dijk underlines - from the context, in relation to the enunciation scene and the way the enunciators define their (subjective) point of view. Here, many scholars say, some problems of understanding may appear. If it is true that genre rules are being metabolized simply by living in a culture, maybe a little examination of the process would not hurt. Those who learn about genre from trustful sources possess metagenre competences, that is, the metacognitive abilities to represent and evaluate their own understanding of genre. Those with little interest in metacognitive operations adopt genre rather mimetically, in a genre atmosphere.

The situation of genre as a conceptual instrument able to operate in the entire space of human discourse appears more complicated when we examine not only the emerging genres of literature and art, but also the genres whose "ontological" status is nonfictional but becomes fictional at exponential speed: blogs and social networks are just two examples. Speaking of the circulation of forms/ forms of circulation of cultural goods in the current global context, anthropologists (Arjun Appadurai, among others) note that these change radically: if literature had (and still has) a constant but slower cultural transfer rate (because we are still talking about books, not just digital products), other forms of cultural communication such as blogs, social networks, photography etc. have infinitely higher transfer rates. They even have an obsession for instantaneity (they are "just one click away") and, very importantly, they create paths and circuits that did not exist previously. These emerging genres, especially those circulating in cyberspace, pose a big problem: fantastic transfer speed and viral dissemination can raise issues regarding the intelligibility of the mental schemata they transport, leading to serious semantic (and, unfortunately, cultural) conflicts.

We cannot fully predict what genre will become. Studies from a cognitive perspective are becoming more consistent - see Peter Stockwell, Lisa Zunshine, Frederick Luis Aldama, J.M. Mandler, John Frow, Marie-Laure Ryan, etc. In my opinion, two ideas excerpted from their studies are of particular interest. The first 
one is the definition of genre as an autopoietic system, i.e. a self-reproducible and self-sustaining system, a definition that comes from Maturana and Varela, goes through Niklas Luhmann and reaches a series of recent researchers (for example, Jerome McGann). Another idea is accredited by Mary Laure Ryan, who investigates the genres of digital artifacts. In the digital environments, Mary-Laure Ryan identifies three (archi)genres/ regimes of textuality: 1. the computer as (co) author; 2. the computer as transmission medium; 3. the computer as theater. The first genre, the computer as co-author, includes computer-generated experimental projects, or ELIZA, the computer program written by Joseph Weizenbaum in 1966 that simulates the dialogue between a patient and a psychotherapist. The second, the computer as transmission medium, includes electronic hybrids of already established genres, such as collaborative fiction or electronic series, while the third, the computer as theater, includes, on one hand, the subgenre of the hypertext in which a text is 'broken' into fragments (lexies, textrons) and stored in a network whose nodes are connected to other electronic pages, and, on the other hand, the important category of videogames.

Although these recent taxonomies seem exotic to classical philology, MarieLaure Ryan argues that the emergence of digitality could have unpredictable effects on the condition of literature: it could fulfil Brecht's or Artaud's dream of total language, combining text, music, dance, visual elements; it could bring us closer to Rimbaud's multisensory poetic language with coloured vowels or to Joyce's instances of synaesthesia; it could reach Lautréamont's ideal of poetry that must be created by all, not by one; or it could invent a multidimensional language with endless semiotic potentials.

\section{BIBLIOGRAPHY}

ADAM, Jean Michel, Les textes: types et prototypes, Paris, Nathan, 1992.

BAKHTINE, Mikhail Esthétique de la création verbale, Paris, Gallimard, 1986.

BARTHES, Roland, Image-Music-Text. Translated by Stephen Heath, London, Fontana Press, 1977.

FAUCONNIER, Gilles and TURNER, Mark, The Way We Think. Conceptual Blending and the Mind's Hidden Complexities, New York, Basic Books, 2002.

GENETTE, Gérard, Fiction et diction, Paris, Seuil, 1991.

GENETTE, Gérard, Introduction à l'architexte, Paris, Seuil, 1979.

RASTIER, François, Arts et sciences du texte, Paris, PUF, 2001.

RYAN, Marie-Laure, Cyberspace Textuality. Computer Technology and Literary Theory, Bloomington, Indiana University Press, 1999.

SCHAEFFER, Jean-Marie, Qu'est-ce qu'un genre littéraire, Paris, Seuil, 1989.

TALEB, Nicholas Nassim, Antifragile: Things That Gain from Disorder, New York, Random House, 2012.

TODOROV, Tzvetan, Les Genres du discours, Paris, Seuil, 1978.

VAN DIJK, Teun, Discourse and Context, Cambridge, Cambridge University Press, 2008.

VAN DIJK, Teun, Discourse and Knowledge, Cambridge: Cambridge University Press, 2014. 


\section{GENRE AS CONCEPTUAL TOOL}

(Abstract)

My paper is a metatheoretical reflection upon genre as a conceptual and taxonomic tool. Whether we refer to its semantic values (which describe the "spirit', "vision' or "mode' of the texts) or the syntactic ones (which analyse the structuring laws and functions), genre is, essentially, a sociodiscursive contract and a user's guide to cultural artefacts. My research is particularly interested in a conceptual history of emancipation and resistance, investigating the complex ways in which genre proves its anti-fragility, resisting change and adapting to the 20th century critical paradigms.

Keywords: genre, archigenre, metagenre, essentialism, conditionalism, literariness, formalism, cognitivism.

\section{GENUL CA INSTRUMENT CONCEPTUAL (Rezumat)}

Lucrarea propune o reflecție metateoretică despre gen ca instrument conceptual și taxonomic. Indiferent dacă ne referim la valorile sale semantice (descriind „spiritul”, ,viziunea” sau „,modul de a fi" al textelor) ori la cele sintactice (vizând legile și funcțiile compoziției textuale) genul reprezintă, în primul rând, un contract socio-discursiv și un ghid pentru înțelegerea artefactelor culturale. Astfel, această cercetare discută mai ales o istorie conceptuală a emancipării și rezistenței, analizând modurile prin care genul își demonstrează „anti-fragilitatea”, rezistența la schimbare și adaptarea la paradigmele critice ale secolului XX.

Cuvinte-cheie: gen, arhigen, metagen, esențialism, condiționalism, literaritate, formalism, cognitivism. 